\title{
The impact of clean lifestyle health promotion on the attitude, motivation, and behaviour of village health cadres
}

\author{
Pengaruh promosi kesehatan Perilaku Hidup Bersih dan Sehat (PHBS) \\ terhadap sikap, motivasi, dan perilaku kader kesehatan di desa
}

\author{
Tetti Solehati ${ }^{1}$, Agus Rahmat $^{2}$, Cecep Eli Kosasih ${ }^{3}$, \& Nur Oktavia Hidayati ${ }^{4}$ \\ ${ }^{1}$ Department of Maternity, Faculty of Nursing, Universitas Padjadjaran \\ ${ }^{2}$ Faculty of Communication, Universitas Padjadjaran \\ ${ }^{3}$ Department of Medical-Surgical Nursing, Faculty of Nursing, Universitas Padjadjaran \\ ${ }^{4}$ Department Mental of Health, Faculty of Nursing, Universitas Padjadjaran \\ Address: Jalan raya Bandung Sumedang KM 21 Jatinangor, West Java 45363 \\ Email: tsh_tetti@yahoo.com \\ Phone: 081224836837
}

\begin{abstract}
Pangandaran is a popular tourism destination in West Java, which is annually visited by a high number of foreign and domestic tourists. It has set itself the vision of gaining the title 'Healthy Village'. However, Pangandaran beach is still fighting the problem of waste, which is easily found along the coast. Thus, disease is mushrooming due to the lack of a Clean Lifestyle (Perilaku Hidup Bersih Sehat/PHBS) and the low awareness of $P H B S$ in the Pangandaran local community. The efforts undertaken to overcome the problem of infectious disease due to the lack of $P H B S$ require great support from various parties such as health service centres and via community participation and the role of cadres, who also manage the Community Health Centres (Pos Pelayanan Terpadu/Posyandu). The study aims to determine the effect of the health promotion of PHBS on the attitude, motivation, and behaviour of the health cadres. The study was quasi-experimental, involving a pre-test and post-test design. The study was conducted in Pangandaran Village, Pangandaran Regency. This research involved the health cadres because they are the closest person to the community and they also run a health program. In addition, they are reliable people when it comes to overcoming health problems in the community. The total population of health cadres in Pangandaran Village amounted to 28 people, via total sampling. The instruments used in this study included a questionnaire, observation sheet, and a check list. The data analysis used univariate and bivariate analysis. The result showed that the mean score of attitude ranged from 65.11 to $74.71(p=0,000)$, the mean score of motivation was 37.39 to $40.71(p=0,000)$, the mean score of genital hygiene behaviour was 67.96 to $80.61(\mathrm{p}=0,000)$ and the mean score of the behaviour of CTPS was significant at 32.25 to $35.71(p=0,000)$. This study found there to be significant difference in the mean attitude, motivation and behaviour of the health cadres before and after the intervention period.
\end{abstract}

Keywords: health cadres; health promotion; $P H B S$

Abstrak
Pangandaran sebagai salah satu tempat wisata di Jawa Baratyang ramai dikunjungi wisatawan mancanegara
maupun domestic memiliki visi menjadi Desa Sehat. Sayangnya masih banyak ditemukan sampah di sepanjang
pantai dan penyakit akibat Perilaku Hidup Bersih dan Sehat (PHBS) karena kesadaran ber-PHBS masyarakat
Pangandaran masih rendah. Upaya untuk mengatasi masalah tersebut memerlukan dukungan berbagai pihak
baik dari pusat pelayanan kesehatan maupun dari peran serta masyarakat dalam bentuk peran kader yang
tergabung dalam posyandu. Tujuan penelitian untuk mengetahui pengaruh promosi kesehatan PHBS terhadap
sikap, motivasi, dan perilaku kader kesehatan. Metodepenelitianyang digunakan adalah desain penelitian quasi
eksperimen dengan rancangan pre test dan post test. Penelitian dilakukan di Desa Pangandaran Kabupaten
Pangandaran. Populasi penelitian adalah seluruh kader kesehatan di Desa Pangandaran berjumlah 28 orang
dengan sampel total responden. Penelitian dilakukan pada kader kesehatan karena merupakan orang yang
terdekat dengan masyarakat dan merupakan perpanjangan tangan dari tim kesehatan yang diandalkan dalam
mengatasi masalah kesehatan Instrumen menggunakan kuesioner, lembar observasi, dan lembar cek list.
Analisis. Data menggunakan analisis univariat dan bivariat. Hasil penelitian terdapat peningkatan rata-rata
sikap dari 65.11 menjadi 74.71 (p =0,000), terdapatpeningkatan rata-rata motivasi dari 37.39 menjadi 40.71 
$(p=0,000)$, terdapat peningkatan rata-rata perilaku genital hygiene yang signifikan dari 67.96 menjadi 80.61 $(p=0,000)$, terdapat peningkatan rata-rata perilaku pola CTPS yang signifikan dari 32.25 menjadi 35.71 ( $p$ =0,000) Simpulan penelitian adalah ada perbedaan bermakna rerata sikap, motivasi, dan perilaku kader kesehatan sebelum dan setelah periode intervensi.

Kata kunci: perilaku kader kesehatan; PHBS; promosi kesehatan; perilaku masyarakat

\section{Introduction}

Pangandaran is one of the tourism destination objects in East Java with numerous domestic and international tourist visits annually. Its main vision is to become a Healthy Village (Pemerintah Daerah Kabupaten Pangandaran 2017). Unfortunately, many of the residents are not yet aware of the importance of having a Clean and Healthy lifestyle (Perilaku Hidup Bersih Sehat/PHBS). The data provided by the Pangandaran Community Health Centre (2016) shows that diseases caused by a lack of a clean and healthy Lifestyle such as typhoid, Acute Respiratory Infections (ARI), diarrhoea, and worm-diseases are high. In Pangandaran, tourism is mainly focused on infrastructure development, thus considering the health component is less significant.

Initial research conducted in Pangandaran Beach from 2016-2017 found that waste was easily found along the beach or in the sea, which are the areas that attract the most tourists when it comes to activities such as building sand houses, cycling, riding horses and swimming. This situation is mainly due to the difficulty of finding a place to put garbage on the beach. There are also no facilities to wash or to clean the body after doing many of the activities on the beach. In addition, many street food and beverage sellers sell their goods on the beach without covering the items that they offer to tourists. Sellers often pick the food using their bare hands. Fish sellers do not wear gloves or aprons. Toilet facilities on the beach also do not meet the health standards, and many tourists spit wherever they wish.

From the health perspective, in 2016 many campus students were infected by diarrhoea and typhoid due to a lack of hygiene related to the food that they bought. Fishermen in the area also admit that the number of DHF was high. Street food sellers did not immediately throw water from the buckets they used when it accumulated. Thus, the water possibly become the breeding ground for mosquitoes. Food sellers around the beach informed the researcher that trash is all over the coast line because tourists throw the rubbish inconsiderately because they are lacking the awareness to keep the environment clean. Other than that, tourists and sellers are not well-informed about waste-sorting mechanisms. Thus, they do not throw away organic and non-organic waste separately. Pangandaran also does not have proper waste management. Even though citizens have proposed trash bin procurement, the proposal was left unrealised. Sellers and fishermen stated that the lack of waste management leads to a dirty environment which causes many diseases such as diarrhoea and dengue fever. They wish that all parties have the right level of awareness to maintain the environment, so then it is clean and healthy because such behaviour will solve the waste-related problems in the beach.

The beach is also home to a group of deer. Therefore, the problem of deer faeces in the beach also complicates the waste problem in general. According to local people, there is no particular activity that is undertaken to clean up the deer faeces that are spread all over the beach line because they think that the waste will be gone with the rain.

The Head of the Development Planning Agency at the Sub-National Level (Badan Perencanaan Pembangunan Daerah/BAPPEDA) in Pangandaran Regency stated that Pangandaran is expected to be a world class tourism destination, thus the problem of waste on the beach needs to be addressed immediately by implementing PHBS. The Pangandaran Government has become the pilot of the project through the Healthy Community Movement (Gerakan Masyarakat Sehat/GERMAS). Developments in the health sector are intended to increase awareness, willingness and the ability of realising a healthy lifestyle for people to reach the highest level of the health index. To support the 
accomplishment of the Strategic Plan of Ministry of Health 2010-2014 according to the Republic of Indonesia Ministerial Health Decree No. 2269/MENKES/PER/XI/2011 concerning PHBS guidance, a clean and healthy environment in relation to various aspects needs to be improved such as in the household, education settings, public spaces, work place and health care centres.

Research on basic health (Riset Kesehatan Dasar/Riskedas) in 2007 revealed that the households in Indonesia that practice $P H B S$ only amounted to $38.7 \%$. The lack of awareness of $P H B S$ often leads to health problems such as infection related to female reproduction, urinary tract infection, diarrhoea, and worm-disease. Death in toddlers and children are mostly caused by diarrhoea. Washing hand using hygienic soap properly will decrease the risk of diarrhoea by about $42 \%$, and up to $47 \%$ (UNICEF Indonesia 2002). Unfortunately, many people are still not aware of the importance of washing their hand. The national prevalence of washing hand is only $23.2 \%$.

Given the lack of PHBS behaviour found as part of the research background, researchers are keen to address the questions about PHBS promotion's influence toward the motivation, attitude, and behaviour of the health cadres in Pangandaran village.

\section{Research Method}

This research applied a quasi-experimental research methodology involving a pre-test and post-test design. The research was conducted in Pangandaran Village in Pangandaran Regency between July and October 2017. The population of Health Cadres in Pangandaran was 28 people. Researchers applied the total sampling technique because the research population was relatively low (Sugiyono 2011). The research instruments used were questionnaire, observation form, and check list. The analysis of the data was performed through univariate and bivariate t-test analysis. The research method applied concerned the health promotion program; $P H B S$ in households and $P H B S$ in general (for the first year). Health Cadres were given health education and a simulation of washing the hands using soap (Cuci tangan pakai sabun/CTPS). This was in addition to a design used to build tools for CTPS. Education about health and disease prevention was also provided.

Methods used in relation to the health promotion were Interactive Discussions using power point and pictures related to the material, Focus Group Discussions, and Videos. Before and after the health promotion, the cadres were given a questionnaire to measure their behaviour, attitude, and motivation. The behaviour measurements post-intervention were conducted one month after the health promotion.

\section{Result and Discussion}

The people of Pangandaran Village commonly work as fishermen or merchants around the beach. As a tourism destination, they are expected to be able to perform PHBS behaviour in order to maintain the attractiveness of Pangandaran Beach. According to Soedarso (2016), social behaviour in a local community heavily influences the tourism destination's condition. The lack of supportive attitude toward the environment causes many diseases (Puskesmas Pangandaran 2016). In addition, the beauty of the beach is highly deteriorated due to inconsiderate behaviour.

\section{Demographic data}

Before the health promotion program was implemented, the health cadres were required to fill in demographic data. The researchers also conducted pre-test screening related to knowledge, motivation, and behaviour regarding PHBS. The results from the pre-test have been displayed in Table 1 as follows.

Table 1 summarises that most of the respondents' ethnicity was Javanese, making up 15 respondents $(53.6 \%)$. All of them were Muslim and 22 people's education was at the highest level of attainment, which in this study was Junior High School (78.6\%). Eight people worked as labourers (28.6\%), with the same percentage applied to other occupation. 
Table 1.

Demographic frequency distribution of the Health Cadres in the Integrated Service Post in Pangandaran in $2017(n=28)$

\begin{tabular}{|c|c|c|}
\hline Characteristic & $f$ & $\%$ \\
\hline \multicolumn{3}{|l|}{ Ethnicity } \\
\hline Sundanese & 13 & 46,4 \\
\hline Javanese & 15 & 53,6 \\
\hline \multicolumn{3}{|l|}{ Religion } \\
\hline Islam & 28 & 100 \\
\hline Others & 0 & 0 \\
\hline \multicolumn{3}{|l|}{ Education } \\
\hline Little/less education & 1 & 3,6 \\
\hline Junior high school & 22 & 78,6 \\
\hline Senior high school & 4 & 14,3 \\
\hline University & 1 & 3,6 \\
\hline \multicolumn{3}{|l|}{ Occupation } \\
\hline Housewife & 5 & 17,9 \\
\hline Labour & 8 & 28,6 \\
\hline Self-employed & 7 & 25,0 \\
\hline Other & 8 & 28,6 \\
\hline \multicolumn{3}{|l|}{ Information } \\
\hline Yes & 28 & 100 \\
\hline No & 0 & 0 \\
\hline \multicolumn{3}{|c|}{ Genital hygiene information through printed media } \\
\hline Yes & 6 & 21,4 \\
\hline No & 22 & 78,6 \\
\hline \multicolumn{3}{|c|}{ Genital hygiene information through health officer } \\
\hline Yes & 24 & 85,7 \\
\hline No & 4 & 14,3 \\
\hline \multicolumn{3}{|l|}{ CTPS facilities } \\
\hline Yes & 28 & 100 \\
\hline No & 0 & 0 \\
\hline \multicolumn{3}{|l|}{ CTPS information from parents } \\
\hline Yes & 8 & 28,6 \\
\hline No & 20 & 71,4 \\
\hline \multicolumn{3}{|l|}{ CTPS information from relatives } \\
\hline Yes & 3 & 10,7 \\
\hline No & 25 & 89,3 \\
\hline \multicolumn{3}{|l|}{ CTPS information from friends } \\
\hline Yes & 2 & 7,1 \\
\hline No & 26 & 92,9 \\
\hline \multicolumn{3}{|l|}{ CTPS information from social media } \\
\hline Yes & 12 & 42,9 \\
\hline No & 16 & 57,1 \\
\hline \multicolumn{3}{|l|}{ CTPS information from printed media } \\
\hline Yes & 5 & 17,9 \\
\hline No & 23 & 82,1 \\
\hline \multicolumn{3}{|l|}{ CTPS from information from health officer } \\
\hline Yes & 23 & 82,1 \\
\hline No & 5 & 17,9 \\
\hline
\end{tabular}

Source: Data analysed by the researchers 
All of the respondents received information about PHBS. Six people (21.4\%) gained the information from printed media. Almost every respondent received genital hygiene information from a Health Officer (24 people/85.7\%).

All of the respondents had CTPS facilities in their home. All of them had also previously been informed about CTPS. Parents being the source of CTPS information was admitted to by eight respondents $(28.6 \%)$. Three of the respondents got the information from their relatives $(10.7 \%)$ and two of them were informed by their friends $(7.1 \%)$. Half of the respondents got the information about CTPS from social media (12 people/42.9\%), and 23 of them gained the information from a Health Officer (82.1\%).

From the respondents' education level, most of them held the highest education level in this study, which was middle school. Thus, they are ready to accept information that could influence knowledge, attitude, motivation and behaviour. According to Jo (2003), 509 South Korean citizens were given health promotion information and they concluded that social norms and education affect personal behaviour.

Most of respondents were already informed about $P H B S$. However, the lack of supportive behaviour and motivation in Pangandaran remains unaddressed. According to Brempong (2013), the low practice of $P H B S$ was not due to inadequate knowledge, but because of the low motivation to make progression.

From the locus of information gathering, the results show that the respondents also receive information from the media. Media has a great impact on its receiver, which can influence their behaviour. Research from Wakefield (2010) revealed that mass media campaigns could contribute to positive development or prevent a negative transformation concerning health-related behaviour issues.

\section{Attitude, motivation and behaviour}

It is apparent from Table 2 that there was a significant behaviour average difference from 65.11 to $74.71(p=0,000)$, a significant motivation average difference from 37.39 to $40.71(p=0,000)$, a genital hygiene behaviour average difference from 67.96 to $80.61(p=0,000)$, and a CTPS behaviour average difference from 32.25 to $35.71(p=0,000)$.

Table 2.

Average knowledge, behaviour, motivation and attitude of Pangandaran Health Cadres before and after intervention in 2017 ( $n=28)$

\begin{tabular}{lccccrrr}
\hline \multirow{2}{*}{ Variable } & \multicolumn{2}{c}{ Pre intervention } & \multicolumn{2}{c}{ Post intervention } & \multirow{2}{*}{$\mathbf{t}$} & $\mathbf{p}$ \\
\cline { 2 - 5 } & $\mathbf{M}$ & $\mathbf{S D}$ & $\mathbf{M}$ & $\mathbf{S D}$ & & \\
\hline Attitude & 65.11 & 4.54 & 74.71 & 3.82 & -13.47 & 0,000 \\
Motivation & 37.39 & 3.73 & 40.71 & 3.98 & -9.96 & 0,000 \\
Genital hygiene behaviour & 67.96 & 5.91 & 80.61 & 3.39 & -13.00 & 0,000 \\
CTPS behaviour & 32.25 & 4.95 & 35.71 & 3.10 & -6.01 & 0,000 \\
\hline \multicolumn{5}{l}{ Source: Analysed by the researchers }
\end{tabular}

An observation of the Health Cadres in Pangandaran Village found that there was a significant improvement in their behaviour, motivation, and the attitude concerning PHBS in the household and PHBS in the wider environment before and after the intervention was provided. According to the education level, the knowledge, behaviour, motivation, and attitude of the Health Cadres shows that their knowledge about PHBS in general is good. They are actively involved in Maternal and Child Health Service in their area. These cadres' activities in the health sector also evoke high curiosity to learn more about health. In addition, community health centre officers and village officers indicate openness to receiving new information for the sake of the improvement of their cadres. This behaviour has been supportive related to the health program promoted by the researchers. 
The health promotion results show a significant difference before and after the intervention in the aspects of knowledge, behaviour, motivation, and the attitude of PHBS in households and in general $(p=0.000)$. Thus, it was clear that village health cadres need health promotion and training to improve their capabilities when it comes to handling health-related problems in the village. Support and motivation from the Village and Community Health Centre officers need to be improved and sustained. In this sense, motivation plays an important role that influences performance (Alexander 2000, Ardansyah 2014). The higher the motivation, the better people that will perform their job.

Health promotion also adds value by raising the openness in the respondents' way of thinking. Research conducted by Salem (1999) on 148 health care workers in Saudi Arabia was also supported by Abiola (2013), who observed 104 nursing students in Nigeria. Their results showed that education lead to a significant impact to the respondents' motivation and behaviour. Good motivation will create more proactive health cadres when it comes to influencing citizen's behaviour related to achieve the expected outcomes. Wijaya (2013) revealed that health cadres with a high motivation will be 15 times more likely to become more active compared to health cadres with a low level of motivation. Kelly (1991) promoted health-care information to 215 respondents and concluded that motivation is an important intervening variable in evaluating health care promotion and measuring the targets' behaviour transformation. Cadres will require a high amount of motivation to achieve the expected results of the program.

Health promotion also influences genital hygiene behaviour and CTPS. As explained by Solehati (2015), elementary school teachers who were given information about CTPS experienced an increase in CTPS skills from 64.17 to 97.92 ( $\mathrm{pv}=0.001$ ). Many people are still not aware of the importance of CTPS. As a consequence, many diseases infect society's citizens, especially in the group who lack an awareness of CTPS. Solehati (2015) explained that the implementation of CTPS behaviour in Indonesia is relatively low due to the lack of awareness in citizens that consider CTPS to be unimportant in their daily life. With the improvement of the health cadres' behaviour when it comes to performing $C T P S$, the public will perceive them as a role model that displays a healthy lifestyle. Health cadres are expected to increase their capacity as a public health advisor, as they perform their role of assisting the health officials. Therefore, the capacity building process will require information via health promotions and training. Suhanda (2008) and Marliati (2008) concluded that training effectivity for a health advisor is an essential factor in developing the health advisors' skill and improving the outcome of the activity.

Coordination from related stakeholders is required to support the PHBS program. The main stakeholders are the Community Health Centre and local government. There is a need to encourage the health cadres to perform effectively and sustainably. Health cadres, as one of the main executors of the Village health-care program, need the Community Health Centre to work accordingly. To achieve sustainability, there are components that need to be considered such as information, operational support and policy support from the local government. The support is expected to improve the health cadres' capacity to resolve health-related problems in the surrounding society. Based on Devi's research on Health Cadres in Southern Sumatera (2016), there are several main components that need to be carefully addressed: experience, training, health-advisor support, data support and government support. The government should provide funds to support the program.

It is also important to develop trust and harmony between the government, local community, and the health cadres, especially in relation to improving PHBS behaviour. Therefore, the local government will not remain passive when it comes to handling the reality of health problems in the area (Sudjatmoko 2017). People's participation and cooperation between the local government and local people is an important factor that determines the output of the program (Kurniasih 2016). In addition, support from the local government in procuring public facilities and creating a social environment with $P H B S$ is an interpersonal factor that influences people to implement the required behaviour.

According to Rukin (2018), the natural resources in Pangandaran Beach are abundant. The implementation of $P H B S$ will increase the attractiveness of the location to tourists. Thus, it is highly possible to achieve the vision set out, in order for Pangandaran to achieve the title of Healthy Village 


\section{Conclusion}

Health promotion in Pangandaran village, East Java, improves the level of knowledge, behaviour, motivation and attitude of the health cadres concerning PHBS in the household and in the environment. Through further empowerment by the health cadres, community health is needed to develop PHBS culture in the community related to "Healthy Village" implementation. Moreover, officials and community health centres need to supervise and monitor the PHBS program.

\section{Acknowledgement}

The authors would like to thank DRPMI Universitas Padjajaran for funding the program. We would also like to express our highest gratitude to Pangandaran Head Village and staff, the Head of Pangandaran Community Health Centre, the Village secretary and staff, the Village midwife, health cadres, and the local residents in Pangandaran. Research and community service was implemented as it was expected due to the active participation of the related parties.

\section{References}

Abiola AO, Ojika BO, Mannir B, Abba SK, Muhammad M, Ibrahim MT, Aschcroft BN, \& Akanmu SS (2013) Effect of health education on the knowledge and attitude to sickle cell disorder and screening practices among school of nursing students in Sokoto, Nigeria. Nig Q J Hosp Med 23 (1):65-8.

Alexander M (2000) Employee performance and discipline problems: A new approach. Journal Canadian Cataloguing in Publician Data: Current Issues Series. Industrial Relations Centre.

Ardansyah \& Wasilawati (2014) Pengawasan, disiplin kerja, dan kinerja pegawai Badan Pusat Statistik Kabupaten Lampung Tengah. Jurnal Manajemen dan Kewirausahaan 16 (2):153-162

Brempong EA, Okyere P, Cross R, \& Adjei RO (2013) Health behavior change: Advancing the utility of Motivational Interviewing (MI) to health promotion. J Addict Res Ther 4:167. doi:10.4172/2155-6105.1000167.

Devi S, Fatchiya A, \& Susanto D (2016) Kapasitas kader dalam penyuluhan Keluarga Berencana di Kota Palembang, Provinsi Sumatera Selatan. Jurnal Penyuluhan 12 (2):144-156.

Jo H, Lee S, Ahn MO, \& Jung SH (2003) Structural relationship of factors affecting health promotion behaviors of Korean urban residents. Health Promotion International 18 (3):229-236.

Kementrian Kesehatan Republik Indonesia (2011) Pedoman Pembinaan Perilaku Hidup bersih dan Sehat (PHBS). Jakarta: Menteri Kesehatan RI.

Kementrian Kesehatan Republik Indonesia (2015) Laporan Kinerja Kemenkes tahun 2015. Jakarta: Menteri Kesehatan RI.

Kelly RB, Zyzanski SJ, \& Alemagno SA (1999) Prediction of motivation and behavior change following health promotion: Role of health beliefs, social support, and self-efficacy. Social Science \& Medicine 32 (3):311-320.

Kurniasih D, Setyoko PI, \& Imron M (2016) Kinerja kelembagaan program Sanitasi Lingkungan Berbasis Masyarakat (SLBM). Masyarakat, Kebudayaan dan Politik 29 (1):14-21.

Marliati, S, Asngari PS, Tjitropranoto P, Saifuddin A (2010) Faktor-faktor penentu peningkatan kinerja penyuluh pertanian dalam memberdayakan petani. Jurnal Penyuluhan 4 (2):92-99.

Mailoa VA, Kurniasari MD, \& Messakh TS (2017) Persepsi warga mengenai perilaku hidup bersih dan sehat di Dusun Kebonan, Semarang. Masyarakat, Kebudayaan dan Politik 30 (3):229-236.

Puskesmas Pangandaran (2016) Laporan Tahunan Puskesmas Pangandaran Tahun 2016. Pangandaran: Dinas Kesehatan Kabupaten Pangandaran.

Pemerintah Daerah Kabupaten Pangandaran (2017) Propil Pangandaran. [Accessed 6 May 2017]. http://www.pangandarankab.go.id/profil-pangandaran. 
Riskesdas (2008) Riset Kesehatan Dasar 2007, Laporan Nasional 2007. Jakarta: Badan Penelitian dan Pengembangan Kesehatan Kemenkes RI.

Rukin (2018) Economic development as a way to fight against poverty in a coastal society. Masyarakat, Kebudayaan dan Politik 31 (2):230-240.

Salem KA, Balahmar MK, Milaat W, \& Gabal MS (1999) The effects of a training program on knowledge, attitude and practice of the staff of primary health care centers towards growth monitoring: an intervention study. J Egypt Public Health Assoc 74 (5-6):627-49.

Soedarso, Sutikno, \& Sukardi (2016) Strategi pengembangan pariwisata daerah dan pemberdayaan masyarakat di Parigi Moutong. Masyarakat, Kebudayaan dan Politik 29 (3):159-166.

Solehati T, Susilawati S, Lukman M, \& Kosasih EK (2015) Pengaruh edukasi terhadap pengetahuan dan skill guru serta personal hygiene siswa SD. KEMAS 11 (1):135-143.

Solehati T, Susilawati S, Lukman M, Kosasih EK, \& Paryati SPY (2017) Effect of school community empowerment model towards handwashing implementation among Elementary school students in Dayeuhkolot Subdistric. Kesmas: National Public Health Journal 11 (3):111-116.

Sugiyono (2011) Metode Penelitian Kuantitaif Kualitatif dan R \& B. Bandung: Alfabeta.

Suhanda NS, Jahi A, Sugihen BG, \& Susanto D (2008) Kinerja penyuluh pertanian di Jawa Barat. Jurnal Penyuluhan 4 (2):100-108.

Sudjatmoko FX \& Setyowati ND (2017) Transformasional kepentingan rakyat dalam perspektif pemberdayaan masyarakat bagi penanganan kemiskinan sosial melalui Government Social Responsibility (GSR). Masyarakat, Kebudayaan dan Politik 30 (2):94-102.

UNICEF Indonesia (2012) Ringkasan Kajian: Air Bersih, Sanitasi, dan Kebersihan. Jakarta: Unicef Indonesia.

Wijaya IMK (2013) Pengetahuan, sikap dan motivasi terhadap keaktifan kader dalam pengendalian tuberkulosis. Jurnal Kemas 8 (2):137-144.

Wakefield MA, Loken B, \& Hornik RC (2010) Use of mass media campaigns to change health behavior. Lancet 376 (9748):1261-1271. 